\title{
\begin{tabular}{l|l}
\hline 말기 암 환자에서 사망 직전 섬망의 발생 & 원저
\end{tabular}
}

\author{
조희정, 김현기, 김경곤, 김유일 ${ }^{1}$, 서상연,", 조경희 ${ }^{2}$, 강희철, 윤방부 \\ 연세대학교 의과대학 신촌세브란스병원 가정의학교실, ${ }^{1}$ 동국대학교 일산병원 가정의학교실, ${ }^{2}$ 국민건강보험공단 일산병원
}

\section{Delirium in the Final Weeks of Terminally Ill Cancer Patients}

Hi Jung Cho, MD, Hyun Ki Kim, MD, Kyung Kon Kim, MD, Yu Il Kim, MD', Sang-Yeon Suh, MD ${ }^{1, *}$, Kyung Hee Cho, $\mathrm{MD}^{2}$, Hee Chul Kang, MD, Bang Bu Youn, MD

Department of Family Medicine, Shinchon Severance Hospital, College of Medicine, Yonsei University, Seoul, ${ }^{1}$ Dongguk University Ilsan Hospital, ${ }^{2}$ National Insurance Corporation Ilsan Hospital, Goyang, Korea

Backgrounds: In terminally ill cancer patients, delirium must be considered to be important clinically and for the quality of life. We reviewed cases of delirium in hospitalized cancer patients with the aim to recognize and treat delirium.

Methods: We reviewed retrospectively the medical records of patients admitted with terminal cancer from April 2003 to April 2004 in the department of family medicine, National Health Insurance Corporation Ilsan Hospital. A total of 71 patients were evaluated with age, sex, oncological diagnosis, metastases, morphine (oral morphine equivalents/day, OME) use and amount, sedatives use, duration from delirium to death, and laboratory findings. Analysis was conducted to find the characteristics of delirium patients and to quantify the relationship between delirium and predicting factors.

Results: Among 71 cases, those patients who developed delirium were 41 (57.7\%). Among them, gastric cancer was the most common diagnosis with 10 patients (24.4\%), followed by colon and lung cancers (9: 22\%, 5: 12.2\%). The patients receiving sedatives or morphines were 24 (58.5\%) and 28 (68.3\%), respectively. The mean amount of morphine was 168.6 $\pm 125.5 \mathrm{mg} \mathrm{OME} /$ day. Hyperbilirubinemia $(4.2 \pm 9.2 \mathrm{mg} / \mathrm{dL})$ and hyponatremia $(132.5 \pm 4.5 \mathrm{mM} / \mathrm{L})$ were found. Not only bone metastasis and the use of morphine or sedatives but serum Na were significant $(\mathrm{P}=0.047 ; \mathrm{P}<0.001 ; \mathrm{P}=0.069 ; \mathrm{P}=$ 0.029). By logistic regression analyses, the occurrence of delirium was increased with decreased serum $\mathrm{Na}$ (odds ratio [95\% CI] 0.798 [0.649-0.981]) and increased use of sedatives (5.955 [1.080-32.835]).

Conclusion: In terminally ill cancer patients, the risk factors of delirium were bone metastasis, the use of morphine or sedatives, and serum Na level. Among these, the use of sedatives and serum Na level were independent risk factors.

Keywords: Delirium; Terminal Cancer; Risk Factors

서론

접수일: 2004년 8월 31일, 승인일: 2009년 4월 2일

*교신저자: 서상연

Tel: 031-961-7490, Fax: 031-961-7969

E-mail:fmmodel@paran.com

Korean Journal of Family Medicine

Copyrights ( 2009 by The Korean Academy of Family Medicine
최근 암은 한국에서 주요한 사망 원인이 되어 왔다. 2003 년 통계청 발표를 보면 우리나라 암(악성신생물) 사망자수는 2003년 한 해 동안 우리나라 전체사망자(24만 6천명)의 $25.9 \%$ 인 6만 4천명(10만 명 당 사망률 131.8 명)으로 암으로 인한 사 망이 전체 사망원인의 1 위를 차지하고 있다. ${ }^{1)}$ 또한 남자인구 10 만 명 당 166.4 명, 여자인구 10 만 명 당 97.0명으로 남여 각각 사망 원인 1위였으며, 2003년 신생물 사망률은 133.1 명으로 암 의 사망률 증가로 인하여 10 년 전 111.0 명 보다 22.1 명 증가된 
수치로 나타났다. 이러한 암의 발생률과 사망률은 비단 우리 나라 뿐만 아니라 세계적으로 증가하는 추세이며, 그로 인한 의료비용 상승과 가족과 사회에 끼치는 여러 가지 영향에 의 한 문제로 국가 정책의 필요성이 대두되고 있다. ${ }^{2)}$

말기 암 환자나 가족, 의사간에 완치나 조절에 목표를 둔 치료가 더 이상 적절하지 않거나 바람직하지 않다고 결론이 난 경우, 흔히 관심을 갖게 되는 것 중 하나가 생존기간을 추정 하는 것이다. ${ }^{3)}$ 임종에 가까운 환자의 정확한 여명을 예측하는 것은 매우 어려운 일이지만 ${ }^{3}$ 삶의 마지막을 준비하는 시점에 서는 생존기간을 정확히 제공하는 것은 환자와 그 가족들에 게 큰 도움이 될 것이다. ${ }^{2)}$

일반적으로 암 환자의 예후를 평가할 때 가장 많이 보는 자료는 암의 종류, 조직검사를 통한 세포종류와 분화도, 진단 시점의 질병의 진행된 정도, 합병증, 환자의 수행능력 등이다. 사실 이것은 암을 처음 발견하고 진단할 때 중요한 지표이지 만, 말기 암 환자의 경우에서는 큰 의미를 갖지 못한다. ${ }^{2}$ 많은 연구자들이 이런 점을 고려하여 연구를 실시하였다. 연구 결 과 저나트륨혈증, 의식혼란, 수행증력 저하, 고빌리루빈혈증, 저혈압 등이 환자의 생존 기간을 단축시키며 통증, 호흡곤란, 섬망 등의 임상증상이 심해질 때 임종이 가까이 왔음을 의미 한다고 하였다. ${ }^{4)}$ 또한 말기 암 환자에서 수행능력의 저하, 중 성구 증가증, 프로트롬빈 시간(prothrombin time, PT) 연장, 활 성부분 트롬보플라스틴 시간(activated partial thromboplastin time, aPTT) 연장이 사망 위험도를 높이는 예후인자라고 하였 다. ${ }^{2)}$

일반 환자에서나 말기 암 환자에서나 섬망은 흔하면서도 심각한 합병증으로 치명률을 높이고 재원기간의 연장 및 지 속을 가져올수 있다.) 말기 암 환자에서 섬망은 임상적으로나 환자의 삶의 질적인 측면에서 매우 중요하게 고려되어야할 문제이다. 그러나 말기 암으로 인한 착란 증상과의 구별이 어 렵고, 이러한 증상이 발생하더라도 환자나 보호자가 임종에 대한 두려움으로 인해 의료진에게 알리지 않는 경우가 많다. 또한 의료진이 관심을 갖지 않아 간과 되는 경우도 적지 않다. 미국의 한 연구에 따르면 중증 질환을 않고 있는 환자의 $92 \%$ 가 의식이 삶의 질에 중요하다고 답한 반면 의료진은 $65 \%$ 만이 중요하다고 답하였다. ${ }^{6}$

저자 등은 임상적으로 말기 암 환자에서 다수의 섬망을 관찰하고 이후 수일 내에 사망하는 경우를 경험하여, 호스피 스 케어가 필요한 환자에서 섬망의 중요성을 인식하는 것이 중요하다고 생각되었다. 이에 저자 등은 입원 중인 말기 암 환 자에서 섬망이 발생하는 경우를 살펴보아 의료진이 섬망을 인지하고치료하는 데 도움이 되고자 한다.

\section{방법}

\section{1. 연구대상}

2003년 4월 1일부터 2004년 4월 30일 사이에 국민건강보 험공단 일산병원 가정의학과에 말기 암으로 입원하여 사망한 환자를 대상으로 하였다. 이들 환자들은 더 이상 암 치료에 효 과가 없는 사람으로 호스피스케어를 받기 위해 입원 또는 전 과된 환자들이었다. 연구 대상자들은 최소 7일 이상의 재원기 간을 가졌으며 진단 받은 지 5 년 이내로서 정신분열증의 과거 력이나 실어증, 실성증 등의 의사소통 장애가 없는 사람으로 한정하였다.

\section{2. 연구방법}

말기 암으로 입원한 환자들의 입원 당시 의무기록을 후향 적으로 조사하였다. 의무기록을 통한 조사항목으로는 인구 통계학적으로 나이와 성별을, 병력으로는 암의 종류, 전이 부 위와 유무, 진단받은 달부터 사망까지의 기간, 진통제로서의 morphine 사용 여부 및 용량, 진정제 사용 여부, 동반질환을, 임 상 증상으로는 입원 첫날 의식변화, 식욕부진, 재원 기간 동안 섬망 발생 유무, 섬망 발생부터 사망까지의 기간을 조사하였 다. 또 입원 첫날 시행한 신체 검사 중 혈압과 혈액 검사로서 백 혈구, 중성구, 간효소(SGPT), 빌리루빈, 크레아티닌, 알부민, 나트륨, 칼슘, 프로트롬빈 시간, 활성부분 트롬보플라스틴 시 간 등을 조사하였다.

섬망의 진단 기준으로 DSM-IV-TR ${ }^{7}$ 를 따라 2 명의 연구자 가 같은 진단을 내리는 경우에 한하였다. 의식 수준의 변동이 지속되면서 계속 의식이 감소되는 상태에서 임종까지 진행되 는 경우와 같이 임종에 의한 의식변화와 구별되지 않는 경우 는제외하였다.

\section{3. 통계분석}

섬망이 발생한 환자군과 섬망이 발생하지 않은 환자군의 특성을 평균, 빈도, 분포도와 카이제곱검정 및 Fisher의 정확 검 정, 스튜던트 $\mathrm{t}$-검정, 로지스틱 회귀분석을 시행하여 비교하였 다. 비연속변수의 분석에서는 카이제곱검정 및 Fisher의 정확 검정을 이용하였으며, 연속변수의 분석에서는 스튜던트 $\mathrm{t}$-검 정을 시행하였다. 단변량 분석에서 유의미한 변수와 기존에 섬망과 연관성이 크다고 알려진 변수를 포함하여 로지스틱 회귀분석을 시행하여 독립적 위험인자를 분석하였다.

모든 분석은 SPSS 11.5 를 이용하였고, 검정의 유의수준은 0.05 로 하였다. 
결과

Table 1. Demographic characteristics and disease-related factors of two groups categorized by presence of delirium.

\begin{tabular}{|c|c|c|c|}
\hline Characteristics & $\begin{array}{c}\text { Groups with } \\
\text { delirium } \\
(\mathrm{N}=41, \%)\end{array}$ & $\begin{array}{c}\text { Groups } \\
\text { without } \\
\text { delirium } \\
(\mathrm{N}=30, \%)\end{array}$ & Pvalue* \\
\hline \multicolumn{4}{|l|}{ Sex } \\
\hline Male & $23(56.1)$ & $14(46.7)$ & 0.43 \\
\hline Female & $18(43.9)$ & $16(53.3)$ & \\
\hline \multicolumn{4}{|l|}{ Age (years) ${ }^{\dagger}$} \\
\hline$<65$ & $11(26.8)$ & $11(36.7)$ & 0.37 \\
\hline$\geq 65$ & $30(73.2)$ & $19(63.3)$ & \\
\hline \multicolumn{4}{|l|}{ Primary cancer site } \\
\hline Stomach & $10(24.4)$ & 5 (16.7) & 0.80 \\
\hline Colon & $9(22.0)$ & $4(13.3)$ & \\
\hline Lung & $5(12.2)$ & 4 (13.3) & \\
\hline Cervix of uterus & $3(7.3)$ & $1(3.3)$ & \\
\hline Biliary tract & $2(4.9)$ & $4(13.3)$ & \\
\hline Liver & $2(4.9)$ & $3(10.0)$ & \\
\hline Pancreas & $2(4.9)$ & $3(10.0)$ & \\
\hline Breast & $1(2.4)$ & $1(3.3)$ & \\
\hline Others & 7 (17.1) & $5(16.7)$ & \\
\hline \multicolumn{4}{|l|}{ Previous treatment } \\
\hline Surgery & $12(29.3)$ & $9(30.0)$ & 0.32 \\
\hline Chemotherapy & $12(29.3)$ & $5(16.7)$ & \\
\hline \multicolumn{4}{|c|}{ and/or radiotherapy } \\
\hline None & $17(41.5)$ & $16(53.3)$ & \\
\hline Distant metastasis & 33 (80.5) & $20(66.7)$ & 0.18 \\
\hline Metastasis to bone & $19(46.3)$ & $7(23.3)$ & 0.04 \\
\hline \multicolumn{4}{|l|}{ Hospital stay (days) } \\
\hline$<15$ & $8(19.5)$ & $13(43.3)$ & 0.09 \\
\hline $15-30$ & $23(56.1)$ & $12(40.0)$ & \\
\hline$>30$ & $10(24.4)$ & 5 (16.7) & \\
\hline Comorbidities & $19(46.3)$ & $15(50.0)$ & 0.76 \\
\hline Morphine use $^{\ddagger}$ & $28(68.3)$ & $0(0.0)$ & $<0.01$ \\
\hline Sedative use & $24(58.5)$ & $11(36.7)$ & 0.06 \\
\hline
\end{tabular}

*P values by chi-square test, ${ }^{\dagger}$ Mean \pm standard deviation of age: $67.3 \pm 13.4$ years, ${ }^{\ddagger}$ Mean \pm standard deviation of morphine usage: $168.6 \pm 125.5 \mathrm{mg}$ OME (oral morphine equivalents) per a day.
기간 내에 사망한 말기 암 환자 119 명 중 재원 일수가 7일 미만인 환자 41 명과 진단 후 사망까지의 기간이 5 년 이상인 환자 7명을 제외하고 71 명의 자료를 얻었으며, 이중 섬망이 발 생한 환자는 41 명(57.7\%)이었다.

연구 대상 중 섬망군의 경우 남자가 23 명 $(56.1 \%)$ 이었 고, 평균 연령은 67.3 세였다. 암의 종류를 보면 위암이 10 명 (24.4\%), 대장암이 9명(22\%), 폐암이 5명(12.2\%)순이었으며 성별, 연령, 암의 종류는 섬망군과 비섬망군이 큰 차이를 보이 지 않았다. 이미 전이가 된 환자는 섬망군이 33명(80.5\%), 비섬 망군이 20명(66.7\%)이었고, 이 중 골전이가 있는 경우는 섬망 군이 19명(46.3\%), 비섬망군이 7명(23.3\%)으로 두 군 간에 유 의한차이가 있었다 $(\mathrm{P}=0.04)$ (표 1).

몰핀을 투여 받은 환자는 28 명(68.3\%)이었으며, 평균 투 여량은 $168.6 \pm 125.5 \mathrm{mg} \mathrm{OME/day이었고,} \mathrm{비섬망군에는} \mathrm{몰핀}$ 을 투여받은 환자가 한명도 없었다 $(\mathrm{P}<0.01)$. 진정제를 사용한 환자는 섬망군이 24 명(58.5\%), 비섬망군이 11 명(63.7\%)이었

Table 2. Clinical presentations and physical examination findings of two groups categorized by presence of delirium.

\begin{tabular}{lccc}
\hline Characteristics & $\begin{array}{c}\text { Groups with } \\
\text { delirium } \\
(\mathrm{N}=41, \%)\end{array}$ & $\begin{array}{c}\text { Groups } \\
\text { without } \\
\text { delirium } \\
(\mathrm{N}=30, \%)\end{array}$ & P value \\
\hline Clinical presentations & & & \\
Altered mentality & & & \\
Yes & $8(19.5)$ & $6(20.0)$ & $0.95^{*}$ \\
No & $33(80.5)$ & $24(80.0)$ & \\
Anorexia & & & \\
Yes & $37(90.2)$ & $27(90.0)$ & $0.97^{*}$ \\
No & $4(9.8)$ & $3(10.0)$ & \\
Physical examination findings & & \\
Systolic blood & & & \\
pressure (mmHg) & & & \\
$<90$ & $1(2.4)$ & $2(6.7)$ & $0.57^{\dagger}$ \\
$\geq 90$ & $40(97.6)$ & $28(93.3)$ & \\
Mental status & & & \\
on admission & & & \\
Alert & $37(90.2)$ & $27(90.0)$ & $1.00^{\dagger}$ \\
Lethargy & $4(9.8)$ & $3(10.0)$ & \\
\hline
\end{tabular}

*By Chi-square test, ${ }^{\dagger}$ By Fisher's exact test. 
Table 3. Serologic characteristics of two groups categorized by presence of delirium.

\begin{tabular}{lccc}
\hline \multicolumn{1}{c}{ Characteristics } & $\begin{array}{c}\text { Groups with delirium }(\mathrm{N}=41) \\
\text { Means (SD) }\end{array}$ & $\begin{array}{c}\text { Groups without delirium }(\mathrm{N}=30) \\
\text { Means (SD) }\end{array}$ & P value* \\
\hline Leukocyte $\left(10^{3} / \mathrm{mm}^{3}\right)$ & $10,707.8(5246.5)$ & $12,480.0(7493.4)$ & 0.24 \\
Neutrophil count (\%) & $78.7(11.3)$ & $78.7(12.2)$ & 0.99 \\
Creatinine (mg/dL) & $1.2(1.2)$ & $1.0(0.5)$ & 0.44 \\
Albumin (mg/dL) & $2.7(0.7)$ & $2.6(0.5)$ & 0.58 \\
Bilirubin (mg/dL) & $4.2(9.2)$ & $1.4(1.3)$ & 0.06 \\
ALT (U/L) & $38.7(47.9)$ & $29.8(20.4)$ & 0.28 \\
Sodium (mM/L) & $132.5(4.5)$ & $135.4(6.5)$ & 0.02 \\
PT (second) & $13.3(2.2)$ & $14.9(5.6)$ & 0.14 \\
aPTT (second) & $33.6(4.2)$ & $35.4(10.7)$ & 0.38 \\
Calcium (mg/dL) & $8.7(1.2)$ & $8.9(1.2)$ & 0.47 \\
\hline
\end{tabular}

*By student t-test.

SD: Standard deviation, ALT: alanine aminotransferase, PT: prothrombin time, aPTT: activated partial thromboplastin time.

Table 4. Logistic regression analysis* of factors related to delirium.

\begin{tabular}{lcc}
\hline \multicolumn{1}{c}{ Characteristics } & Odds ratio & $\begin{array}{c}95 \% \text { confidence } \\
\text { interval }\end{array}$ \\
\hline Metastasis to bone & 2.83 & $0.54-14.84$ \\
Serum sodium & 0.79 & $0.64-0.98$ \\
Morphine use (OME/d) & 1.82 & $0.00-1.88$ \\
Sedative use & 5.95 & $1.08-32.83$ \\
\hline
\end{tabular}

${ }^{*}$ Method of logistic regression is forward selection, ${ }^{\dagger} \mathrm{P}<0.05$ OME/d: oral morphine equivalents per a day.

으며 전체 환자 중 diazepam을 사용하는 경우가 22명(31.0\%), lorazepam은 13명 (18.3\%)이었다. 진정제 사용여부와 섬망 발 생 간에 통계학적 유의성은 나타나지 않았다(표 1). 또한 입원 당시의 의식변화나 식욕부진 여부, 저혈압, 입원 당시 의식 상 태도 두 군 간에 차이가 없었다(표2).

혈액검사상 백혈구수치와 중성구는 두 군에서 모두 증가 되었고, 알부민과 칼슘은 두 군에서 모두 감소되었으나 섬망 군과 비섬망군 간에 유의한 차이는 없었다. 빌리루빈은 섬망 군에서 $4.2 \pm 9.2 \mathrm{mg} / \mathrm{dL}$ 로 증가되었으나 두 군 간의 유의한 차이 는 없었고, 혈중 $\mathrm{Na}$ 의 경우 섬망군에서 $132.5 \mathrm{mM} / \mathrm{L}$ 로 감소되 었으며 두 군 간의 유의한차이가 있었다 $(\mathrm{P}=0.02)$ (표 3).

위에서 본 섬망발생과 유의성이 있는 변수의 로지스틱 회 귀분석 상 혈중 나트륨이 낮을수록(교차비 $0.79,95 \%$ 신뢰구 간 0.64-0.98) 진정제 사용이 증가할수록(교차비 5.95, 95\% 신
Table 5. The time among the day of admission, onset of delirium and death.

\begin{tabular}{lcc}
\hline \multicolumn{1}{c}{ Characteristics } & Mean & $\begin{array}{c}\text { Standard } \\
\text { deviation }\end{array}$ \\
\hline $\begin{array}{l}\text { Onset of delirium } \\
\text { (from the day of admission, days) }\end{array}$ & 13.6 & 14.0 \\
$\begin{array}{l}\text { Time from onset of delirium } \\
\text { to death (days) }\end{array}$ & 13.3 & 11.1 \\
10 d before death, no. (\%) & $21(51.2)$ & \\
7 d before death, no. (\%) & $23(56.1)$ \\
5 d before death, no. (\%) & $29(70.7)$ \\
3 d before death, no. (\%) & $36(87.8)$ \\
\hline
\end{tabular}

뢰구간 1.08-32.83) 섬망 발생이 증가되었다(표 4).

섬망군에서 암 진단 후 사망까지의 평균 기간은 $17.6 \pm 13.6$ 개월이었고, 사망 직전의 입원에서 평균 재원일수는 $25.9 \pm 14.6$ 일, 섬망은 입원 후 $13.6 \pm 14.0$ 일에 발생하였으며, 섬망 후 사망 까지의 평균 기간은 $13.3 \pm 11.1$ 일이었다. 사망 10 일전의 섬망 환자수가 21 명(51.2\%)에서 사망 3일전에는 36명(87.8\%)까지 증가되었다(표 5).

\section{고찰}

암환자에서 섬망의 발생률은 연구에 따라 $8 \%^{8}$ 에서 $85 \%{ }^{9)}$ 
로 매우 다양하게 나타난다. 이것은 연구에 따라서 외래환자 와 입원환자를 포함하였고, 각 환자에 대해 단 한번의 단편적 인 연구를 하였기 때문이다. ${ }^{10)}$ 말기 암으로 입원한 환자 일수 록 섬망 발생률은 높게 나타나서, Massie 등'의 연구에서는 13 명 중 11 명에서 섬망이 발생하기도 했다.

섬망은 그 특성상 약 절반 정도가 정확히 진단되지 않고 간과된다. ${ }^{11}$ 섬망은 3 가지의 subtype으로 나눌 수 있다. 첫째로 hyperactive (agitated) type은 환각, 망상, 격앙, 지남력 장애 등의 증상을 보이며, hypoactive (lethargic) type은 착란, 진정의 특징 이 있다. 마지막으로 위의 두 가지 subtype의 특징이 함께 나타 나는 mixed type이 있다. Hypoactive type과 mixed type이 전체 섬 망의 3 분의 2 를 차지한다고 여겨지지만 의료진들은 뚜렷이 드 러나는 hyperactive type의 섬망 만을 인지하는 경향이 있기 때 문에 대부분 간과되고 있다. ${ }^{8,12}$

일반적으로 섬망의 원인은 저산소증, 전해질 불균형, 패혈 증 등이 가장 확실한 원인으로 알려졌으며 이외에도 수면장 애, 마약성 진통제, 진정제의 사용, 고령, 남성, 인지기능 저하, 음주력, 정신과적 병력, 화상, 수술력, 투석 등이 있다., ${ }^{413)}$ 암환 자를 대상으로 한 연구에서는 섬망의 위험인자로서 고령, 입 원 당시의 인지 장애, 저알부민혈증, 골전이, 혈액암이 유의하 였다. ${ }^{10)}$

임상적으로 고칼슘혈증이 골전이를 의미하기도 하지만, 골전이는 고칼슘혈증과는 독립적으로 섬망과 깊은 관계가 있 다. Minagawa 등 ${ }^{14}$ 의 연구에서 골전이, 특히 척추골과 골반뼈 에 전이되는 경우 통계적으로 유의하였다. 골전이는 질환이 진행되고 있음을 의미하며 병의 중증도를 반영할 수 있다. 본 연구에서는 섬망군에서 골전이가 있는 환자가 19 명 $(46.3 \%)$ 이 었고, 카이제곱검정에서는 유의한 차이가 있었으나 로지스틱 회귀 분석에서는 의미가 없었는데, 이것은 Minagawa 등 ${ }^{14}$ 의 연 구에서는 진정제, 몰핀 등의 섬망에 영향을 줄 수 있는 임상적 요인을 분석하지 않았기 때문에 일 것으로 생각된다. 추후의 연구에서 골전이뿐 아니라 진정제, 몰핀 사용 등을 포함하는 전향적 연구가 필요하리라 생각된다.

몰핀을 투여 받은 섬망군 환자는 28명(68.3\%)이었으며, 평균 투여량은 $168.6 \pm 125.5 \mathrm{mg} \mathrm{OME/day이었고} \mathrm{특이한} \mathrm{점은}$ 비섬망군 환자는 몰핀을 투여받은 경우가 없었다는 점이다. Morita 등에 에 의하면 사망 1 주전 몰핀 사용량이 $120 \mathrm{mg} \mathrm{OME}$ 이상인 경우 사망 3 일 전에 의사소통 장애가 유의하게 나타났 다고 하였으며, 본 연구에서도 섬망 발생 당시 몰핀을 투여한 경우 용량과 상관없이 섬망 발생에 유의하게 나타났다. 몰핀 의 사용에 대한 연구의 결과는 다소 논란이 있어서 본 연구와 마찬가지로 고용량의 몰핀이나 몰핀 대사물이 섬망을 유발할
수 있다는 연구도 있고,15) 몰핀이 여명에 미치는 영향은 없다 고 하는 연구도 있다. ${ }^{2)}$ 말기 암 환자에서 몰핀 투여로 얻을 수 있는 삶의 질 향상이 중요하기 때문에 몰핀 투여를 자제할 이 유는 없을 것이다. 그러나 몰핀을 사용하게 되는 경우에 소량 이라 하더라도 섬망 발생에 대한 적극적인 주의 및 대처가 필 요할 것으로 생각된다. 또한 심한 통증이 섬망의 원인이 될 수 있다지만 ${ }^{16)}$ 말기 암 환자의 통증 자체가 섬망을 유발하는 직 접적 원인이 된다는 연구는 아직까지 없었다. 그러나 통증의 정도를 몰핀의 용량과 비례하여 생각할 수 있다면 통증이 큰 경우 그렇지 않은 경우보다 섬망이 발생할 가능성이 크다고 생각될 수도 있다. 이에 대해서는 좀 더 연구가 필요할 것으로 생각된다.

진정제를 사용한 환자는 섬망군 24 명(58.5\%), 비섬망군 11 명(36.7\%)으로 나타났는데 이것은 2002년에 Ahn 등 ${ }^{17)}$ 에 의해 연구된 진정제 사용률 $35.5 \%$ 에 비하여 매우 높은 수치로서 미 국 $53 \%$, 이탈리아 $52 \%$ 에 비해서도 높았다. 말기 암 환자에서 진정제는 수면 장애 뿐 아니라 심한 통증이나 호흡 곤란 등 잘 조절되지 않는 증상을 조절하기 위해서 선택할 수 있는 마지 막 약물 중 하나이다. 여러 연구에서 진정제의 사용 여부가 말 기 암 환자의 생존에 영향을 미치지 않는다고 알려졌으며 ${ }^{18)}$ 본 연구에서도 카이제곱검정에서 유의하지 않은 결과가 있었 으나 섬망에 대한 일반적인 연구에서는 진정제의 사용이 섬 망 발생에 영향인자로서 작용하는 경우가 다수 있었기 때문 에 로지스틱 회귀분석에 포함하였다. 분석 결과 진정제를 사 용하는 경우 섬망의 발생이 5.955 배( $\mathrm{P}=0.04)$ 증가되는 것으로 나타났다. 이는 섬망의 초기증상인 밤낮이 바뀌는 수면장애 의 치료제로 lorazepam을 사용하여 발생한 혼란변수 때문일 것 으로 생각된다. 또한 $\mathrm{Ahn}$ 등기의 연구에서는 섬망을 조절하는 haloperidol을 포함하였고 본 연구에서는 제외하였는데도 사 용빈도가 높게 나타난 것은 임종이 임박한 환자나 섬망이 이 미 발생한 환자에서 진정제 사용이 증가된 것을 의미한다. 이 것은 diazepam과 haloperidol의 중복사용이 많은 것으로 보아도 알 수 있다. 로지스틱 회귀분석에서 골전이와 몰핀이 의미 없 는 결과가 나온 것도 진정제가 혼란변수로 작용하였을 가능 성이크다.

저나트륨혈증은 전해질 불균형으로서 섬망의 원인이 될 수 있다고 알려져 왔으나 ${ }^{19)}$ 본 연구처럼 말기 암 환자에서 의 섬망 발생 인자로서 뚜렷이 나타난 연구는 아직까지 없었 다. 그러나 저나트륨혈증은 암 환자에서 흔히 발생하는 전해 질 불균형 중 하나이며 대부분 항이뇨호르몬 분비이상 증후 군(syndrome of inappropriate secretion of anti-diuretic hormone, $\mathrm{SIADH}$ )때문인 것으로 알려져 있다. ${ }^{20)}$ 저나트륨혈증의 증상 
은 삼투압에 의해서 세포내 조직액이 증가되어 뇌부종을 유 발하여 발생한다. 초기에는 식욕부진, 오심, 권태감이 오고 이 후 두통, 기면, 혼돈 등 신경학적 이상을 발생하며 혈중 나트륨 의 감소 속도와 정도에 따라 경련이나 혼수가 올 수도 있다. 암 환자에서 SIADH가 발생하는 것을 암의 종류에 따라 항이뇨 호르몬의 이소성 분비가 나타나거나 항암화학치료, 몰핀 등 마약성 진통제, carbamazepine, 선택적 세로토닌 재흡수억제 제(selective serotonin reuptake inhibitor, SSRI)에 의한 자극으로 $\mathrm{ADH}$ 가 분비되기 때문이다. ${ }^{20)}$ 본 연구에서 저나트륨혈증은 일반 환자에서의 섬망 발생 뿐 아니라 말기 암 환자에서 섬망 발생에서 독립변수로서 영향을 미침을 다시 한번 확인하게 되었으나 원인을 확인하지 못하여 부족함이 있다.

혈액검사 상 나타난 고빌리루빈혈증도 또한 전부터 섬 망의 위험인자로서 인식되어 왔다. ${ }^{5,21,22)}$ 고빌리루빈혈증 은 간 부전으로 인한 간성 뇌증에서 유발되는 섬망의 지표 가 될 수 있다. 간성 뇌증은 진행된 간질환에서 흔히 나타나 는 합병증이다. 또한 직접적으로 신경전달물질에 영향을 주 는 bromocriptine, flumazenil 같은 약물에 의해 나타나기도 한 다. ${ }^{23,24)}$ 간성 뇌증에 의한 섬망의 치료에는 haloperidol보다 새 로운 신경 이완제인 risperidone, olazapine이 더 적절한 선택이 될 수 있다. ${ }^{24,25)}$ 본 연구에서 고빌리루빈혈증은 유의한 차이가 없는 것으로 나타났으나 이것은 질병 초기가 아닌 사망이 임 박한 시점에서 혈액 검사가 시행되었기 때문에 발생한 치우 침(bias)때문일 것으로 생각할수 있다.

많은 연구에서 섬망이 발생하는 경우 재원기간이 증가하 였으며) 이로 인한 비용의 증가와 합병증이 발생하였다. 또한 섬망이 치명률을 높이고 임종이 가깝다는 지표로서 의미있다 고 하지만 실제로 섬망이 발생한 경우 더 빨리 사망하는 지, 섬 망이 발생하고 얼마 후에 임종하는 지에 대하여 진행된 연구 는 미미하였다. 본 연구에서 섬망은 평균 입원 후 2 주에 발생 하여 약 2 주 후에 사망하였으며 사망 10 일 전에 섬망이 발생한 환자수가 $51.2 \%$ 로서 의료진뿐 아니라 환자나 보호자가 임종 준비를 위한 시간을 갖도록 하는데 의미가 있다. 섬망 발생 후 사망까지의 기간이 2 주 정도로 나타나는 것을 확인하였으며 대조군 연구로서 골전이, 혈중 나트륨, 진정제, 몰핀 사용이 섬 망의 발생에 영향을 미침을 밝혔지만 섬망 발생 시점을 더욱 정확히 해야 하고 혈액검사 시점이 환자 마다 일관성이 적어 혼란변수나치우침이 발생하였다. 이후의 연구에서는 이러한 변수를 조정하고, 또한 전향적 연구를 통해 섬망의 위험인자 와 섬망으로 인한 생존율 예측이 가능한지 등의 연구가 필요 할 것으로 생각된다.

결론적으로 말기 암 환자에서 골전이나 저나트륨혈증이
있는 경우, 몰핀이나 진정제를 사용하는 경우에 섬망이 발생 할 가능성이 크며, 이 중 진정제 사용과 혈중 나트륨 수치는 섬 망 발생율을 높이는 인자임을 알 수 있다. 이들 인자를 통해 말 기 암 환자에서 섬망을 예측하고 적극적으로 대처할 수 있도 록 해야겠다.

\section{요약}

연구배경: 말기 암 환자에서 섬망은 임상적으로나 환자의 삶 의 질적인 측면에서 중요하게 고려되어야할 문제이다. 섬망 은 말기 암 환자에서 흔하고 심각한 합병증으로 치명률을 높 인다. 본 연구에서는 입원 중인 말기 암 환자에서 섬망이 발 생하는 경우를 살펴보아 의료진이 섬망을 인지하고 치료하는 데 도움이 되고자 한다.

방법: 2003년 4월 1일부터 2004년 4월 30일 사이 국민건강 보험공단 일산병원 가정의학과에 말기 암으로 입원하여 사 망한 환자의 의무기록을 후향적으로 조사하였다. 총 71 명 환자의 나이, 성별, 암의 종류, 전이 여부, 몰핀(oral morphine equivalents/day)의 사용 및 용량과 진정제 사용, 동반질환, 섬망 발생 유무, 섬망 발생부터 사망까지의 기간, 혈압, 임상병리검 사결과 등을 조사하여 섬망군과 비섬망군을 비교하여 그 차 이를 분석하였다.

결과: 71 명의 자료를 얻었으며, 이중 섬망이 발생한 환자 는 41 명 $(57.7 \%)$ 이었다. 섬망군 중 진정제 사용 환자는 24 명 (58.5\%), 몰핀 투여 환자는 28 명(68.3\%)이었으며, 몰핀의 평균 투여량은 $168.6 \pm 125.5 \mathrm{mg} \mathrm{OME} / \mathrm{day}$ 이었다. 혈액검사상 고빌 리루빈혈증 $(4.2 \pm 9.2 \mathrm{mg} / \mathrm{dL})$, 저나트륨혈증 $(132.5 \pm 4.5 \mathrm{mM} / \mathrm{L})$ 의 소견을 보였다. 섬망군과 비섬망군은 골전이 여부와 몰핀 과 진정제 사용에서 유의한 차이가 있었고 $(\mathrm{P}=0.047, \mathrm{P}<0.001$, $\mathrm{P}=0.069)$, 혈중 나트륨수치에서도 유의한 차이가 있었다 $(\mathrm{P}=0.029)$. 로지스틱 회귀 분석 결과 혈중 나트륨이 낮을수록 (교차비 $0.798,95 \%$ 신뢰구간 $0.649-0.981$ ) 진정제 사용이 증 가할 수록(교차비 $5.955,95 \%$ 신뢰구간 1.080-32.835) 섬망 발 생이 증가되었다. 섬망은 입원 후 평균 13.6일(표준편차 14.0 일)에 발생하였으며, 섬망 후 사망까지의 평균 기간은 13.3 일 (표준편차 11.1일)이었다. 섬망이 있던 환자수는 사망 10 일 전 21 명 $(51.2 \%)$ 에서 사망 3 일 전에는 36 명 $(87.8 \%)$ 까지 증가되었 다.

결론: 말기 암 환자에서 섬망의 위험인자는 골전이, 몰핀 및 진정제 사용, 혈중 나트륨 수치였고 이중 진정제 사용과 혈중 나트륨은 독립적 위험인자였다. 섬망 환자 중 절반에서 사망 
10 일 전에 섬망이 발생하였다.

중심단어: 섬망; 말기 암; 위험인자

\section{참고문헌}

1. Korea National Statistical Office. Statistics of major causes of death, 2003. Daejeon: Korea National Statistical Office; 2004.

2. Yeom CH, Choi YS, Lee HR, Hong YS, Park YG. Prediction of life expectancy for terminally Ill cancer patients based on clinical parameters. Korean J Hosp Palliat Care 2002; 5: 111-24.

3. Yun YH, Heo DS, Bae JM, Im SA, Yoo TW, Huh BY, et al. Restrospective cohort study of survival and prognostie factors in patients with terminal cancer. J Korean Cancer Assoc 1998; 30: 384-93.

4. Foster LE, Lynn J. The use of physiologic measures and demographic variables to predict longevity among inpatient hospice applicants. Am J Hosp Care 1989; 6: 31-4.

5. Hwang SW, Kang SW, Kang YG, Choi SG, Lee J, Kim MJ, et al. Risk factors of delirium in elderly inpatients. J Korean Acad Fam Med 2002; 23: 112-21.

6. Morita T, Tei Y, Inoue S. Impaired communication capacity and agitated delirium in the final week of terminally ill cancer patients: prevalence and identification of research focus. J Pain Symptom Manage 2003; 26: 827-34.

7. American Psychiatric Association. Diagnostic and statistical manual of mental disorders (DSM IV-TR). 4th ed. Arlington (VA): American Psychiatric Association; 2000.

8. Lipowski ZJ. Delirium: Acute confusional states. New York: Oxford University Press; 1990.

9. Massie MJ, Holland J, Glass E. Delirium in terminally ill cancer patients. Am J Psychiatry 1983; 140: 1048-50.

10. Ljubisavljevic V, Kelly B. Risk factors for development of delirium among oncology patients. Gen Hosp Psychiatry 2003; $25: 345-52$.

11. Pompei P, Foreman M, Cassel CK, Alessi C, Cox D. Detecting delirium among hospitalized older patients. Arch Intern Med 1995; 155: 301-7.

12. Breitbart W, Strout D. Delirium in the terminally ill. Clin Geriatr
Med 2000; 16: 357-72.

13. Gleason OC. Delirium. Am Fam Physician 2003; 67: 1027-34.

14. Minagawa H, Uchitomi Y, Yamawaki S, Ishitani K. Psychiatric morbidity in terminally ill cancer patients: a prospective study. Cancer 1996; 78: 1131-7.

15. Morita T, Tei Y, Tsunoda J, Inoue S, Chihara S. Increased plasma morphine metabolites in terminally ill cancer patients with delirium: an intra-individual comparison. J Pain Symptom Manage 2002; 23: 107-13.

16. Wahlund L, Bjorlin GA. Delrium in clinical practice: experiences from a specialized delirium ward. Dement Geriatr Cogn Disord 1999; 10: 389-92.

17. Ahn $\mathrm{MH}$, Yeom $\mathrm{CH}$, Lee HR. The factual survey of using sedative agents in terminal cancer patients. J Korean Acad Fam Med 2002; 23: 521-6.

18. Stone P, Phillips C, Spruyt O, Waight C. A comparison of the use of sedatives in a hospital support team and in a hospice. Palliat Med 1997; 11: 140-4.

19. Aldemir M, Ozen S, Kara IH, Sir A, Bac B. Predisposing factors for delirium in the surgical intensive care unit. Crit Care 2001; 5: 265-70.

20. Flombaum CD. Metabolic emergencies in the cancer patient. Semin Oncol 2000; 27: 322-34.

21. Morita T, Tei Y, Tsunoda J, Inoue S, Chihara S. Underlying pathologies and their associations with clinical features in terminal delirium of cancer patients. J Pain Symptom Manage 2001; 22: 997-1006.

22. Levkoff SE, Safran C, Cleary PD, Gallop J, Phillips RS. Identification of factors associated with the diagnosis of delirium in elderly hospitalized patients. J Am Geriatr Soc 1988; 36: 1099104.

23. Pomier-Layrargues G, Giguere JF, Lavoie J, Perney P, Gagnon S, D'Amour M, et al. Flumazenil in cirrhotic patients in hepatic coma: a randomized double-blind placebo-controlled crossover trial. Hepatology 1994; 19: 32-7.

24. Sipahimalani A, Masand PS. Use of risperidone in delirium: case reports. Ann Clin Psychiatry 1997; 9: 105-7.

25. Breitbart W, Tremblay A, Gibson C. An open trial of olanzapine for the treatment of delirium in hospitalized cancer patients. Psychosomatics 2002; 43: 175-82. 